\title{
KARAKTERISTIK ES KRIM BENGKUANG DENGAN MENGGUNAKAN BEBERAPA JENIS SUSU
}

\section{Bengkoang Ice Cream Characteristics with Difference Kind of Milk}

\author{
Failisnur \\ Balai Riset dan Standardisasi Industri Padang \\ JI. Raya LIK No. 23 Ulu Gadut Telp. (0751) 72201 Fax.(0751) 71320 Padang 25164 \\ e-mail: failisnur@gmail.com
}

Diterima: 6 Februari 2013, Disetujui: 30 April 2013

\begin{abstract}
ABSTRAK
Es krim merupakan produk olahan susu beku berbentuk padat dengan penambahan bahan lain yang dibuat melalui proses pembekuan dan agitasi. Prinsip pembuatan es krim adalah membentuk suatu rongga udara pada campuran bahan-bahan es krim sehingga dihasilkan pengembangan volume yang membuat es krim menjadi lebih ringan, tidak terlalu padat dan mempunyai tekstur yang lembut. Tujuan penelitian adalah untuk melihat pengaruh dari penggunaan beberapa jenis susu terhadap sifat fisik, kimia dan organoleptik es krim bengkuang yang dihasilkan. Penelitian dilakukan dengan perlakuan penggunaan susu fullcream, susu kental manis, susu kedelai bubuk, kacang hijau bubuk, dan susu kedelai cair. Es krim yang dihasilkan dilakukan uji fisika overrun dan kecepatan meleleh, analisis kimia kadar protein, lemak dan uji organoleptik rasa dan tekstur. Hasil penelitan menunjukkan bahwa penggunaan susu kedelai bubuk menghasilkan nilai overrun dan kecepatan meleleh yang baik yaitu $37,2 \%$ dan 10,1 menit, kandungan protein dan lemak yang cukup tinggi yaitu 6,9\% dan $13,08 \%$, serta organoleptik rasa dan tekstur yang disukai.
\end{abstract}

\section{Kata Kunci: Bengkuang, susu, es krim}

\section{ABSTRACT}

Ice cream is a frozen dairy solid product with the addition of other materials that are made through the process of freezing and agitation. The principle of its making to form a cavity of air in the mixture of ice cream ingredients to produce a volume that made the development of the ice cream into a lighter, less dense and has a soft texture. The purposed of the research to see influence the use of a variety of milk to the physical properties, chemical properties and organoleptic to the bengkoang ice cream produced. Research carried out by treatment type of milk used that were fullcream milk, sweetened condensed milk, soy milk powder, green bean powder, and soy milk liquid. The ice cream produced was tested the physics of overrun and melting speed, chemical analysis of protein content, fat and organoleptic of taste and texture. Research results showed that the best treatment was the use of soy milk powder where the value of overrun $37.2 \%$, melting speed 10.1 minutes, protein content $6.9 \%$, fat $13.08 \%$, and organoleptic of taste and texture was preferred.

Keywords: Bengkoang, milk, ice cream

\section{PENDAHULUAN}

Umbi tanaman bengkuang (Pachyrrhizus erosus) mempunyai manfaat yang sangat banyak baik untuk pangan, kesehatan dan kecantikan. Untuk kesehatan, bengkuang memiliki khasiat sebagai obat diantaranya untuk mengatasi penyakit kulit, diabetes, demam, eksim, sariawan, dan wasir. Sedangkan untuk kecantikan, bengkuang mampu berfungsi sebagai pelembab (softening), pencerah (lightening) dan pemutih (whitening).

Pada pangan, bengkuang biasanya dimanfaatkan sebagai buah segar, dibuat rujak, atau asinan. Sifat fungsional dari 
bengkuang menyebabkan komoditi ini banyak digemari, sedangkan pengolahan bengkuang untuk produk olahan makanan masih belum banyak dilakukan.

Potensi bengkuang yang cukup melimpah di Sumatera Barat, dimana produksi setiap tahunnya rata-rata 2.834 ton (BPS, 2004). Penganekaragaman produk olahan dari bengkuang disamping dapat memberikan nilai tambah juga merupakan salah satu cara dalam melaksanakan program pemerintah daerah guna peningkatan ketahanan pangan serta mengembangkan industri pengolahan pangan berbasis potensi bahan baku daerah.

Umbi bengkuang sebagai bahan baku pembuatan es krim dapat berfungsi sebagai padatan bukan lemak karena kandungan dekstrin yang terdapat dalam umbinya. Dekstrin juga bersifat sebagai penstabil, sehingga penggunaan bengkuang dalam pembuatan es krim tidak memerlukan lagi penambahan emulsifier. Hasil penelitian yang telah dilakukan oleh Yeni, dkk (2007), ternyata kandungan karbohidrat bengkuang dapat berfungsi sebagai emulsifier. Dekstrin dan serat bengkuang dapat mengentalkan adonan es krim dan membentuk jaringan atau molekul kecil yang dapat mengikat air yang banyak pada adonan es krim sehingga dapat mencegah terjadinya kristalisasi.

Komponen penting lainnya dalam pembuatan es krim adalah susu. Susu adalah salah satu pangan hasil ternak yang paling mudah dan cepat untuk dicerna dibanding pangan hasil ternak lainnya seperti telur dan daging. Susu mengandung beberapa senyawa bioaktif yang memiliki efek kesehatan yang signifikan. Senyawa bioaktif susu diantaranya adalah protein susu, laktosa, asam-asam lemak dan mineral, terutama kalsium. Hal ini menyebabkan produk-produk turunan susu juga masih memiliki efek fungsional, termasuk es krim. (Astawan, 2010).

Susu sebaiknya dikonsumsi setiap hari untuk menunjang dan memenuhi gizi yang dibutuhkan tubuh, terutama pada mereka yang kurang gizi. Akan tetapi banyak diantaranya yang tidak terbiasa untuk mengonsumsi susu seperti layaknya di negara-negara yang sudah berkembang (Nur, 2012). Penggunaan susu pada produk olahan dapat menjadi pangan alternatif yang diminati sekaligus meningkatkan pola konsumsi susu harian.

Protein dan lemak susu sangat penting dalam pembentukan tekstur dan cita rasa es krim yang diinginkan. Setiap jenis susu mempunyai kandungan protein dan lemak yang berbeda sehingga akan menghasilkan es krim dengan karakteristik yang berbeda. Untuk itu perlu penelitian karakteristik es krim bengkuang dengan menggunakan beberapa jenis susu, sehingga dihasilkan es krim yang memiliki nilai lebih dengan perpaduan antara susu dan bengkuang sebagai pangan fungsional.

\section{METODOLOGI PENELITIAN}

\section{Bahan}

Bahan yang digunakan dalam pembuatan es krim bengkuang adalah sebagai berikut; umbi bengkuang, susu bubuk skim, susu bubuk fullcream, susu kental manis, susu kedelai bubuk, kacang hijau bubuk, susu kedelai cair, gula pasir, telur, santan, garam, air serta kemasan.

\section{Alat}

Peralatan yang digunakan antara lain; ice cream maker, blender, mixer, freezer/ refrigerator, dan peralatan pengujian yaitu labu kjedahl dan soxlet.

\section{Metoda Penelitian}

Pada penelitian ini rancangan yang digunakan adalah acak lengkap (RAL), dengan 3 kali ulangan. Variasi perlakuan adalah pemakaian jenis susu yang digunakan yaitu; susu bubuk fullcream $(A)$, susu kental manis $(B)$, susu kedelai bubuk (C), bubuk kacang hijau (D), dan susu kedelai cair (E).

\section{Prinsip Pembuatan Es Krim}

Proses pembuatan es krim terdiri dari pencampuran bahan, pasteurisasi, homogenisasi, aging di dalam refrigerator, pembekuan sekaligus pengadukan di dalam ice cream maker, dan pengerasan (hardening) di dalam freezer (Astawan, 2010). Tujuan masing-masing langkah kerja adalah: 


\section{a. Pasteurisasi}

Tujuan utama pasteurisasi adalah membunuh mikroba patogen yang ada dalam susu dan mengusahakan seminimum mungkin kehilangan gizinya serta mempertahankan semaksimal mungkin sifat fisik dan cita rasa susu segar (Abubakar dkk, 2001), melarutkan bahan-bahan kering, meningkatkan cita-rasa, memperbaiki mutu es krim, memperpanjang umur produk dan menghasilkan produk yang seragam.

\section{b. Homogenisasi}

Homogenisasi bertujuan untuk menyebarkan globula lemak secara merata ke seluruh produk, mencegah pemisahan globula lemak ke permukaan selama pembekuan dan untuk memperoleh tekstur yang halus karena ukuran globula lemak kecil, dan protein dapat mengikat air bebas lebih merata. Manfaat homogenisasi yaitu bahan campuran menjadi sempurna, mencegah penumpukan dispersi globula lemak selama pembekuan, memperbaiki tekstur dan kelezatan, mempercepat aging, meningkatkan kekentalan dan menurunkan daya buihnya (Campbell dan Marshall, 1975; Widiantoko, 2011).

\section{c. Aging}

Aging merupakan proses pemasakan campuran es krim dengan cara mendiamkan adonan selama 3-24 jam dengan suhu $4^{\circ} \mathrm{C}$ atau di bawahnya. Tujuan aging yaitu memberikan waktu pada stabilizer dan protein susu untuk mengikat air bebas, sehingga akan menurunkan jumlah air bebas. Perubahan selama aging adalah terbentuk kombinasi antara stabilizer dan air dalam adonan, meningkatkan viskositas, campuran jadi lebih stabil, lebih kental, lebih halus, dan tampak mengkilap.

Pembekuan pada es krim harus terjadi secara cepat untuk memperoleh kristal es yang kecil dan tekstur yang lembut. Pembekuan disertai dengan pengocokan untuk membekukan cairan dan memasukkan udara ke dalam campuran es krim sehingga mengembang.

\section{d. Pengerasan}

Proses kristalisasi es terbentuk karena pelepasan panas pada saat suhu air diturunkan yang akan mengakibatkan pergerakan-pergerakan molekul air diperlambat. Bila air didinginkan terus sampai suhu $4^{\circ} \mathrm{C}$ suatu pola baru ikatan hidrogen akan terbentuk, dan ketika panas dilepas lagi setelah suhu air mencapai $0^{\circ} \mathrm{C}$ maka terbentuklah kristal es. Semakin cepat proses pengerasan es, kristal es yang terbentuk semakin kecil dan tekstur es krim yang dihasilkan semakin lembut. Proses pengerasan dianggap cukup bila suhu bagian tengah produk telah mencapai $-18^{\circ} \mathrm{C}$. Suhu pengerasan ini terutama ditentukan oleh suhu medium pendinginan, kecepatan pergerakan udara pendingin dan suhu awal produk (Widiantoko, 2011).

\section{Pelaksanaan Penelitian}

Proses pembuatan es krim dari bengkuang untuk setiap perlakuan adalah sebagai berikut; (1) Umbi bengkuang dikupas kulitnya dan dicuci. Daging umbi kemudian dipotong-potong sebanyak $2 \mathrm{~kg}$, (2) Dihaluskan dengan blender tanpa air, (3) 2 butir telur dikocok sampai mengembang, (4) 1 liter santan (patinya saja yang diperas dari 1,5 butir kelapa) dan bengkuang yang telah dihaluskan ditambahkan gula sebanyak $400 \mathrm{~g}$, kemudian dimasak sampai mendidih $\left( \pm 80^{\circ} \mathrm{C}\right) .(5)$ Ditambahkan susu sebanyak $200 \mathrm{~g}$ atau $200 \mathrm{ml}$ untuk susu kental manis dan susu kedelai cair (sesuai perlakuan) sambil apinya dikecilkan dan diaduk perlahan, (6) Campuran yang telah dipanaskan tadi dimasukkan ke kocokan telur sambil dikocok dengan mixer, (7) Adonan diaging dalam refrigerator selama \pm 4 jam, lalu dituang ke dalam ice cream maker dan aduk selama 10-15 menit. (8) Adonan lalu dimasukkan dalam wadah es krim kemudian disimpan dalam refrigerator selama 12- 24 jam untuk pengerasan, (9) Es krim siap disajikan. Diagram Alir Pembuatan Es Krim adalah seperti Gambar 1. 


\author{
Umbi Bengkuang \\ $\downarrow$ \\ Kulit umbi dikupas, \\ cuci, dan potong \\ $\Downarrow$ \\ Daging buah \\ diblender \\ $\downarrow+$ santan, gula pasir \\ Dimasak $\left(85-100^{\circ} \mathrm{C}\right)$ \\ $\downarrow+$ Susu \\ Pasteurisasi $\left(70-80^{\circ} \mathrm{C}\right)$ \\ $\downarrow+$ Kocok telur \\ Di kocok dengan mixer \\ $\Downarrow$ \\ Di aging dalam refrigerator \\ $\Downarrow$ \\ Diaduk dalam \\ Ice cream maker \\ ॥ \\ Pengerasan dalam freezer \\ $\Downarrow$ \\ Siap disajikan
}

Gambar 1. Diagram alir pembuatan es krim bengkuang

\section{Analisis dan Pengamatan}

Pengamatan yang dilakukan terhadap es krim meliputi uji fisika yaitu overrun dan kecepatan meleleh, uji kimia yang meliputi, protein (metoda Kjedahl, lemak (metoda soxlet) dan pengamatan organoleptik oleh 15 orang panelis terhadap rasa, tekstur (mouthfeel), warna dan aroma menggunakan skala hedonik skala 1-5 dengan penilaian tidak suka sampai sangat suka.

\section{Overrun (Sathe, 1982).}

Overrun adalah jumlah peningkatan volume yang disebabkan karena masuknya udara ke dalam campuran es krim. Es krim yang telah diagitasi (pembekuan dan pengadukan) selanjutnya dimasukkan ke dalam wadah/kemasan es krim, lalu dibekukan dalam freezer selama \pm 24 jam. Es krim kemudian diletakkan pada suhu ruang dan diukur waktu yang dibutuhkan sampai es krim meleleh sempurna. Hitung persentase pengembangan volume es krim dengan rumus:

$\%$ Overrun $=\underline{\text { Volume es krim }- \text { Volume ICM) }} \times 100 \%$ Volume ICM

Keterangan: $\mathrm{ICM}=$ Ice Cream Mix (adonan es krim).

Kecepatan meleleh dan daya ikat air (Hubeis et al., 1996).

Kecepatan meleleh merupakan waktu yang dibutuhkan es krim untuk meleleh sempurna dan sifat mengikat air meru-pakan kemampuan untuk mempertahankan kandungan air agar tetap pada bahan. Es krim yang berkualitas baik adalah es krim yang resisten terhadap pelelehan. Waktu pelelehan dan daya ikat air akan diukur dengan metode sebagai berikut:

- Es krim dituang dalam wadah kemudian dimasukkan dalam freezer dan dibiarkan selama 24 jam.

- Es krim lalu disimpan pada suhu ruang dan dicatat waktu yang dibutuhkan sampai es krim benar-benar mencair sempurna.

\section{HASIL DAN PEMBAHASAN}

\section{Uji Fisika}

\section{Overrun}

Hasil analisis terhadap overrun es krim bengkuang adalah seperti Gambar 2. Dari jenis susu yang digunakan, ternyata susu kental manis mempunyai nilai overrun tertinggi $(41,3 \%)$. Tingginya nilai overrun dari es krim yang menggunakan susu kental manis disebabkan oleh banyaknya udara yang terperangkap di dalam adonan sewaktu proses pembekuan karena sedikitnya bahan padatan dan kecilnya ukuran partikel dari susu kental manis yang digunakan. Sedangkan pada penambahan kacang hijau bubuk, ukuran partikel lebih besar dan banyak mengandung serat yang dapat menghambat masuknya udara ke dalam adonan es krim sewaktu pembekuan sekaligus pengadukan. 
Overrun mencerminkan kemampuan pembuihan dan kemantapan buih yang berkaitan dengan penurunan tegangan permukaan pada sistem yang terdiri atas udara dan air, yang disebabkan absorbsi oleh molekul protein. Molekul protein yang fleksibel seperti beta-kasein dapat secara cepat mengurangi tegangan permukaan sehingga memberikan daya buih yang baik sedangkan protein globular yang terutama sebagai penyusun protein nabati sulit untuk mengurangi tegangan permukaan sehingga memberikan daya buih yang rendah (Sathe, 1982).

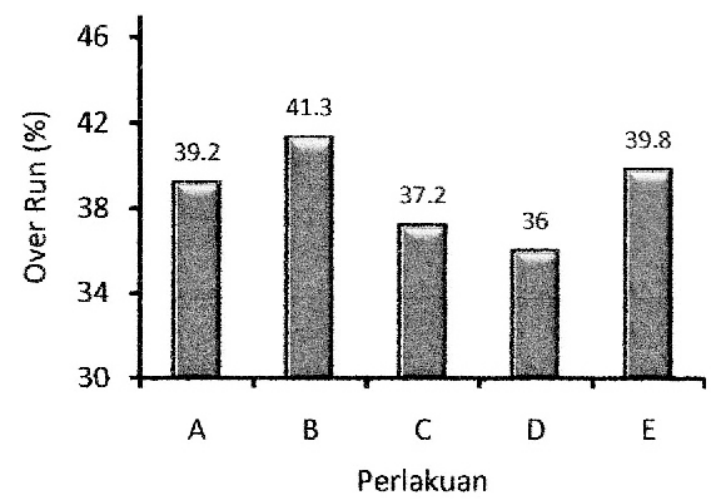

Keterangan;

$A=$ Susu fullcream, $B=$ Susu kental manis, $C=$ Susu kedelai bubuk, $D=$ Kacang hijau bubuk, dan $E=$ Susu kedelai cair.

\section{Gambar 2. Hasil pengamatan overrun es krim bengkuang}

Overrun menunjukkan banyak sedikitnya udara yang terperangkap di dalam campuran es krim atau ICM karena proses pembekuan. Overrun mempengaruhi tekstur dan kepadatan yang sangat menentukan kualitas es krim. Adanya udara dalam ICM akan membentuk rongga-rongga udara yang akan segera terlepas bersamaan dengan melelehnya es krim. Semakin banyak rongga udara akan menyebabkan es krim cepat menyusut dan meleleh pada suhu ruang.

Es krim yang berkualitas memiliki overrun $70-80 \%$, sedangkan untuk industri rumah tangga adalah $35-50 \%$ (Suprayitno dkk, 2001; Padaga dan Sawitri, 2005). Pada semua perlakuan ditinjau dari nilai overrun, maka tergolong pada es krim industri rumah tangga. Hal ini dikarenakan suhu setelah proses aging kurang dingin dan pengadukan sangat lambat sehingga sedikit udara yang terperangkap dalam adonan. Overrun dapat dihasilkan karena pengocokan yang dilakukan ketika proses pembekuan berlangsung. Pengocokan menyebabkan udara dapat masuk dalam campuran es krim sehingga meningkatkan volume adonan es krim (Istini dan Zatnika, 2007; Failisnur, 2010).

Berbagai standar produk makanan membolehkan penggelembungan campuran es krim dengan udara sampai dengan volumenya menjadi dua kalinya (maksimum $100 \%$ overrun). Es krim dengan kandungan udara lebih banyak akan terasa lebih cair dan lebih hangat sehingga tidak enak dimakan (Ismunandar, 2004).

Turunnya nilai overrun disertai dengan semakin tahannya es krim terhadap proses pelelehan dari suhu beku ke suhu ruang sehingga diperlukan waktu yang lebih lama untuk melelehkan es krim. Dari hasil pengamatan terhadap kecepatan meleleh es krim bengkuang, terlihat bahwa es krim dengan overrun rendah (Gambar 2) memiliki kecepatan meleleh yang lebih lama (Gambar 3 ) saat disajikan pada suhu ruang.

\section{Kecepatan Meleleh dan daya ikat air}

Hasil analisis terhadap kecepatan meleleh es krim bengkuang adalah seperti Gambar 3. Kecepatan meleleh merupakan waktu yang dibutuhkan es krim untuk meleleh sempurna. Sedangkan daya ikat air merupakan kemampuan adonan untuk mempertahankan air dalam bahan .

Kecepatan meleleh dari perlakuan pemakaian kacang hijau bubuk lebih tinggi (10,5 menit) yang berarti lebih lama mencair pada suhu ruang dibandingkan dengan jenis susu lainnya. Es krim yang paling cepat meleleh adalah pada pemakaian susu kedelai cair (5,6 menit). Tekstur dari susu kedelei cair lebih ringan dan halus sehingga daya ikat airnya lebih rendah. Es krim yang bertekstur kasar dan rendah total padatannya akan memiliki resistensi terhadap pelelehan yang rendah, sehingga akan mudah meleleh (Arbuckle, 2000). Disamping itu kecepatan meleleh juga dipengaruhi oleh kadar lemak es krim. Kadar lemak es krim berbahan susu kedelai cair lebih rendah $(9,2 \%)$ dibanding perlakuan lainnya. Menurut Roland et al, (1999) waktu leleh es 
krim akan semakin cepat pada es krim dengan kadar lemak rendah.

Perlakuan pemakaian bubuk kacang hijau memberikan kecepatan meleleh yang lebih lama, disebabkan kandungan padatan dan seratnya lebih banyak. Serat dalam bahan pembentuk adonan es krim dapat meningkatkan kandungan padatan dalam adonan es krim yang menyebabkan adonan semakin kental. Hal ini disebabkan oleh kemampuan serat mengikat air yang menyebabkan kadar air menjadi rendah dan es krim menjadi lebih padat sehingga waktu pelelehan akan semakin lama (Failisnur, 2010; Oksilia, 2012).

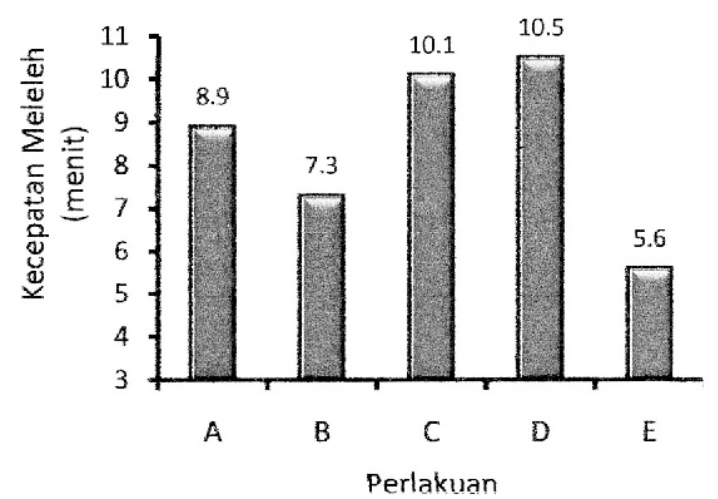

Keterangan;

$A=$ Susu fullcream, $B=$ Susu kental manis, $C=$ susu kedelai bubuk, $\mathrm{D}=$ Kacang hijau bubuk, dan $\mathrm{E}=\mathrm{Susu}$ kedelai cair.

Gambar 3. Hasil pengamatan kecepatan meleleh es krim bengkuang dengan menggunakan beberapa jenis susu.

Kualitas meleleh yang baik pada es krim berkisar 10-20 menit pada suhu kamar (Arbuckle et al, 2000; Flores et al, 1992). Dari semua perlakuan yang memenuhi persyaratan adalah pemakaian susu kedelai bubuk dan kacang hijau bubuk. Es krim dengan waktu pelelehan yang cukup tinggi sangat cocok untuk daerah tropis.

Kecepatan meleleh es krim berbanding terbalik dengan persentase overrun. Kecepatan meleleh es krim sangat dipengaruhi oleh bahan-bahan yang digunakan dalam pembuatan es krim. Es krim yang baik adalah es krim yang tahan terhadap pelelehan pada saat dihidangkan pada suhu ruang. Es krim yang cepat meleleh kurang disukai karena es krim akan cepat mencair begitu disajikan. Es krim yang lama mencair pada suhu ruang juga kurang disukai karena bentuk es krim yang tetap padat begitu disajikan sehingga memberikan kesan terlalu banyak padatan yang digunakan (Padaga, dan Sawitri, 2005).

\section{Uji Kimia}

\section{Kadar Protein}

Hasil analisis kadar protein es krim bengkuang diperoleh data seperti Gambar 4. Kadar protein tertinggi diperoleh pada es krim menggunakan susu kedelai bubuk dan terendah pada es krim dengan pemakaian susu kedelai cair. Hal ini disebabkan karena susu kedelai cair sudah mengalami proses pengenceran sehingga kandungan proteinnya menjadi berkurang.

Protein dalam pembuatan es krim berfungsi untuk menstabilkan emulsi lemak setelah proses homogenisasi, menambah citarasa, membantu pembuihan, meningkatkan dan menstabilkan daya ikat air yang berpengaruh pada kekentalan dan tekstur es krim yang lembut dan meningkatkan nilai overrun es krim (Padaga dan Sawitri, 2005). Protein juga dapat mempertahankan smoothy pada produk akhir, mampu menaikkan overrun tanpa terbentuknya tekstur yang berkeping-keping dan mengurangi total padatan.

Proses pemanasan dapat menyebabkan protein mengalami reaksi denaturasi. Reaksi ini merupakan terurainya untaian polipeptida protein yang berbentuk alpha heliks menjadi rangkaian lurus. Hal ini terjadi akibat dari terlepasnya ikatan-ikatan (seperti sulfur) sehingga menurunkan kadar protein secara kualitatif. Syarat mutu es krim menurut Buckle et al (1987) ditetapkan bahwa kandungan protein pada es krim minimum sebesar $2,7 \%$ dan bila dibandingkan dengan kadar protein es krim hasil penelitian berarti kadar protein es krim ratarata memenuhi standar mutu es krim kecuali yang menggunakan susu kedelai cair. 


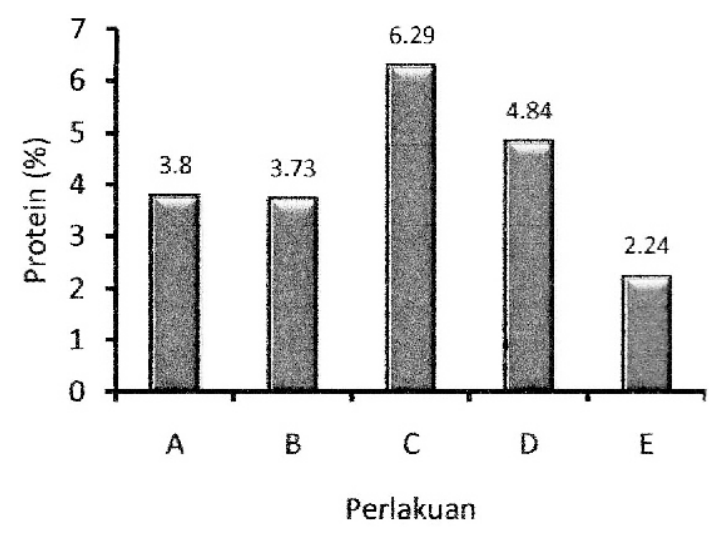

Keterangan;

$A=$ Susu fullcream, $B=$ Susu kental manis,$C=$ susu kedelai bubuk, $\mathrm{D}=$ Kacang hijau bubuk, dan $\mathrm{E}=\mathrm{Susu}$ kedelai cair.

Gambar 4. Hasil analisis kadar protein es krim bengkuang dengan menggunakan beberapa jenis susu

\section{Kadar Lemak}

Hasil analisis terhadap kadar lemak es krim bengkuang adalah seperti Gambar 5 . Kandungan lemak tertinggi diperoleh pada perlakuan penggunaan susu fullcream yaitu $16.5 \%$ dan lemak terendah pada perlakuan pemakaian susu kedelai cair. Tingginya kadar lemak es krim berbahan susu fullcream disebabkan karena kandungan lemak dari bahan bakunya (fullcream) lebih tinggi dibandingkan susu lainnya, sedangkan susu kedelai cair yang sudah mengalami proses pengenceran dan lemak kedelai yang cukup rendah menyebabkan es krim yang dihasilkan mengandung kadar lemak yang lebih rendah.

Es krim dengan kandungan lemak yang rendah mengakibatkan tekstur es krim tidak lembut, memberikan sensasi dingin yang lebih besar dibanding es krim dengan kadar lemak tinggi (Aime et al., 2001) juga dapat digunakan oleh konsumen yang menghindari konsumsi pangan berlemak. Es krim dengan kandungan lemak minimum 10\% dan total padatan $36 \%$, akan menghasilkan es krim dengan nilai overrun lebih tinggi, sehingga harganya lebih murah (Anonim, 2005). Overrun merupakan parameter yang sangat penting dalam pembuatan es krim karena dapat menentukan tingkat harga. Jika overrun yang dihasilkannya tinggi maka keuntungan yang diperoleh juga lebih tinggi. Peningkatan kadar lemak dapat mengurangi pembentukan kristal es dan tingkat pelelehan karena lemak dapat meningkatkan viskositas sehingga kristal es dan waktu pelelehan dapat diperpanjang (Roland et al, 1999).

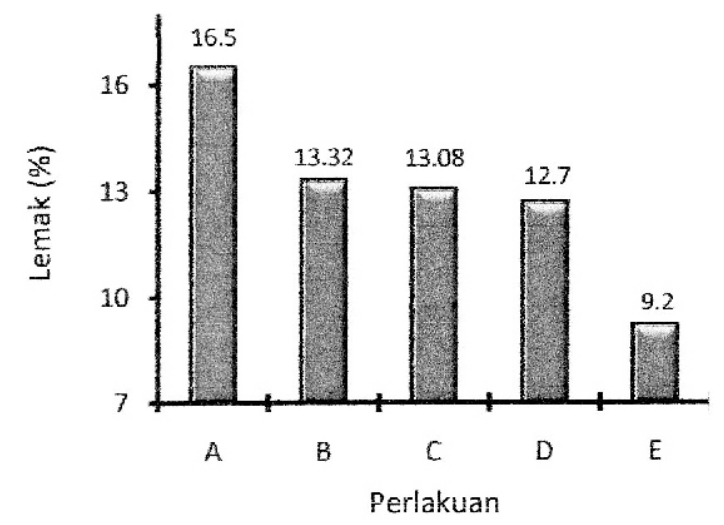

Keterangan;

$A=$ Susu fullcream, $B=$ Susu kental manis, $C=$ susu kedelai bubuk, $\mathrm{D}=$ Kacang hijau bubuk, dan $\mathrm{E}=$ Susu kedelai cair.

Gambar 5. Hasil analisis kadar lemak es krim bengkuang dengan menggunakan beberapa jenis susu.

Lemak susu pada es krim berfungsi untuk meningkatkan nilai gizi es krim, menambah citarasa, menghasilkan karakteristik tekstur yang lembut, membantu memberikan bentuk dan kepadatan, serta memberikan sifat meleleh yang baik (Padaga dan Sawitri, 2005).

\section{Uji Oganoleptik Rasa dan Tekstur Es Krim}

Hasil uji organoleptik rasa dan tekstur dari es krim bengkuang dengan menggunakan skala hedonik adalah seperti pada Gambar 6. Dari penilaian terhadap rasa dan tekstur oleh panelis pada es krim bengkuang didapatkan bahwa rasa dan tekstur di mulut (mouthfeel) yang paling disukai adalah pemakaian susu kental manis. Hal ini disebabkan karena bengkuang mengandung padatan dan serat yang cukup tinggi sehingga penggunaan dari susu kental manis memberikan rasa yang lebih disukai, tekstur lebih lembut, tidak cepat meleleh dan 
nilai overrun yang cukup mengembang. Peningkatan terhadap rasa diiringi juga meningkatnya nilai tekstur es krim bengkuang.

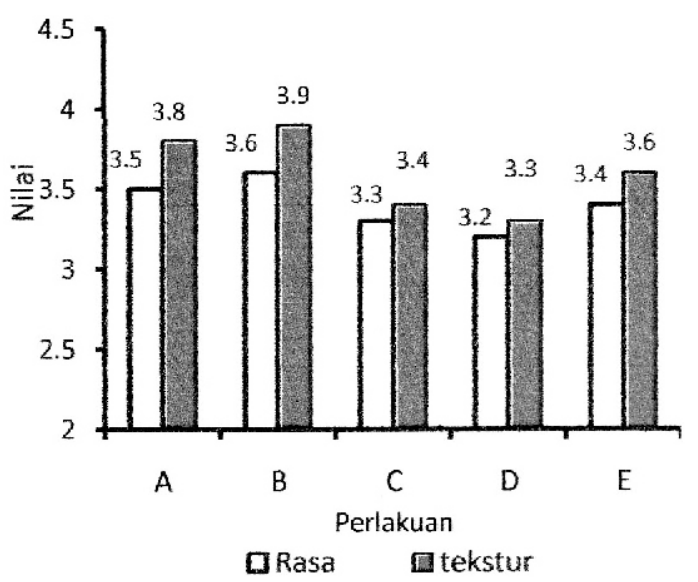

Keterangan;

$A=$ Susu fullcream, $B=$ Susu kental manis,$C=$ susu kedelai bubuk, $D=$ Kacang hijau bubuk, dan $E=$ Susu kedelai cair.

Gambar 6. Hasil uji organoleptik rasa dan tekstur es krim bengkuang dengan menggunakan beberapa jenis susu.

Rasa dalam es krim merupakan kombinasi cita rasa, tekstur dan aroma, sebagai satu kesatuan yang diciptakan untuk memenuhi selera konsumen. Menurut Padaga (2005), rasa sangat mempengaruhi tingkat kesukaan konsumen terhadap es krim, bahkan dapat menjadi faktor penentu utama. Rasa es krim juga dipengaruhi oleh pengental yang dapat mengurangi rasa manis gula dan perubahan tekstur (mouthfeel) yang dapat merubah citarasa es krim.

Tekstur es krim dipengaruhi oleh ukuran dari kristal es, globula lemak, gelembung udara yang terperangkap dan kristal laktosa (Suprayitno et al, 2001; Abdullah et al, 2003). Sementara menurut Padaga dan Sawitri (2005), tekstur lembut es krim sangat dipengaruhi oleh komposisi es krim, cara mengolah dan kondisi penyimpanan. Tekstur es krim yang baik adalah halus, lembut (smooth), creamy dan tidak keras serta tampak mengkilap. Tekstur yang buruk adalah greasy (terasa ada gumpalan lemak), grainy (terasa seperti tepung), flaky/snowy (terasa ada serpihan es), lumpy/gelatin (seperti jelly) dan sandy (berpasir) (Arbuckle et al, 2000; Suprayitno et al, 2001).

Dalam pembuatan es krim biasanya ditambahkan emulsifier seperti karagenan untuk mencegah timbulnya kristal es yang besar dan cita rasa (flavour) serta mouthfeel yang baik (Winarno, 2002). Penggunaan bengkuang sebagai bahan baku dalam pembuatan es krim sekaligus berfungsi sebagai penstabil yang dapat meningkatkan dan menstabilkan daya ikat air yang berpengaruh pada viskositas dan tekstur es krim yang lembut (Oksilia, 2012), sehingga penambahan bahan penstabil tidak diperlukan lagi.

\section{KESIMPULAN DAN SARAN}

\section{Kesimpulan}

Dari hasil penelitian penggunaan beberapa jenis susu terhadap sifat fisik, kimia dan organoleptik dari es krim bengkuang dapat disimpulkan bahwa perlakuan terbaik diperoleh pada penggunan susu kedelai bubuk yang menghasilkan nilai overrun dan kecepatan meleleh yang baik yaitu $37,2 \%$ dan 10,1 menit, kadar protein dan lemak yang cukup tinggi yaitu $6,9 \%$ dan $13,08 \%$, serta organoleptik oleh 15 orang panelis terhadap rasa dan tekstur adalah rata-rata disukai (4).

\section{Saran}

Untuk mendapatkan es krim yang tinggi serat dengan tekstur yang baik, pengolahan bengkuang dilakukan dengan menggunakan blender tanpa air.

\section{DAFTAR PUSTAKA}

Abubakar, Triyantini , Sunarlim, R, Setiyanto, H. dan Nurjannah. 2001. Pengaruh Suhu Dan Waktu Pasteurisasi Terhadap Mutu Susu Selama Penyimpanan. Jurnal IImu Ternak dan Veteriner Vol. 6 No. 1 Th. 2001. 
Abdullah, M., Rehman, S., Zubair, Saeed, M., Kousar, S., and Shahid, M. 2003. Effect of skim milk in soymilk blend on the quality of ice cream. Pakistan Journal of Nutrition 2 (5): 305-311, 2003.

Aime, D. B., S. D. Arntfield, L. J. Malcolmson and D. Rayland. 2001. Textural analysis of fat reduced vanilla ice cream products. Food Res. Int. 34: 237-246.

Anonim. 2005. Ice cream formulation. Dairy Science and Technology. University of Guelph. http//www.ice cream/ formulation. [17 Mei 2005]

Arbuckle, W.S. and Marshall, R.T. 2000. Ice Cream. Chapman and Hall, New York. 145.pp.

Astawan, M. 2010. Teknologi Pengolahan Pangan dan Gizi. IPB : Bogor.

Badan Pusat Statistik Propinsi Sumatera Barat. 2004. Sumatera Barat Dalam Angka. Bekerjasama dengan Bappeda Sumatera Barat.

Buckle K A., R. A. Edwards, G. H. Fleet dan M. Wooton. 1987. Ilmu Pangan. Terjemahan: H. Purnomo dan Adiyono. Penerbit Universitas Indonesia, Jakarta.

Campbell, J.R dan R.T. Marshall. 1975. The Science of Providing Milk for Men. Mc Graw Hill Book, New York.

Failisnur. 2010. Pemanfaatan bengkuang sebagai bahan baku dalam pembuatan es krim. Buletin BIPD Vol.XX No. 1 Tahun 2011.

Flores, R.J., J. Kliptel dan J. Tobias. 1992. Ice Cream and Frozen Dessert. In : Dairy Science and Technology Series. Handbook 3.Y.H. Hui (ed). VHC Publisher Inc, New York.
Hubeis, M., Andarwulan, N., dan Yunita, M. 1996. Kajian Teknologi dan Finansial Produksi Es Krim (Melorin) Skala Kecil. Buletin Teknologi dan Industri Pangan. ITB. Vol. VII (1).

Ismunandar. 2004. Dibalik Lembutnya Es Krim. Departemen Kimia FMIPA ITB. http://www.kimianet.lipi.go.id/utama.cg i?artikel\&1102121768\&1 [8 Agustus 2011]

Istini, S., dan Zatnika, A. 2007. Pengaruh Jenis Dan Konsentrasi Semi-Refined Carrageenan (Src) Sebagai Stabilisator Terhadap Kualitas Es Krim. Jurnal Sains dan Teknologi Indonesia Vol. 9 No. 1 April 2007 HIm. 27-33.

Nur, K. 2012. kualitas es krim dengan penambahan umbi kentang (solanum tuberosum I.) sebagai bahan penstabil. [Skripsi] Program Studi Teknologi Hasil Ternak Jurusan Produksi Ternak Fakultas Peternakan Universitas Hasanuddin Makassar.

Oksilia, Merynda Indriyani Syafutri ${ }^{\star}$, dan Eka Lidiasari. 2012. Karakteristik Es Krim Hasil Modifikasi Dengan Formulas! B u b u r T i m u $\mathrm{n}$ u r i (Cucumis Melt:, L.) Dan Sari Kedelai. Jurnal Teknologi dan Industri Pangan, Vol. XXIII No. 1 Th. 2012, hal. 17-22.

Padaga, M. dan M.E Sawitri. 2005. Es Krim Yang Sehat. Trubus Agrisarana. Surabaya.

Roland, A.M., L. G. Phillips dan K.j. Boor. 1999. Effect of fat content on the sensory properties, melting, colour and hardness of ice cream. J. Dairy Sci. 82: 32-38.

Sathe, S.K., Deshpande, S.S. dan Salunkhe, D.K. 1982. Functional Properties of Winged Bean (Phosphocarpus) tetragonolobus (LDC) Proteins. Journal of Food Science Vol. 47. Hal.85-509. 
Suprayitno, E, Kartika Ningsih, dan S Rahayu. 2001. Pembuatan Es Krim Dengan Menggunakan Stabilisator Natrium Alginat dari Sargassum sp. Jurnal Makanan Tradisional Indonesia ISSN: 1410-8969 Vol.1 No.3. hal 23-27

Widiantoko, R.K. 2011. Es Krim. http://lordbroken.wordpress.com/2011/ 04/10. [Diakses tanggal 3 Oktober 2011]
Winarno, F. G. 2002. Pangan, Gizi, Teknologi dan Konsumen. PT Gramedia, Jakarta.

Yeni G., Failisnur, Firdausni, Marlusi dan Hasni. 2007. Pengembangan Pengolahan Aneka Produk Olahan Dari Bahan Baku Bengkuang. Komunikasi No. 221 Balai Riset dan Standardisasi Industri Padang. 